\title{
PENGGUNAAN DAUN UBI KAYU (Manihot esculenta) DENGAN PENGOLAHAN BERBEDA TERHADAP PERFORMA KAMBING PERANAKAN ETAWA JANTAN
}

\section{The Use of Cassava Leaf (Manihot esculenta) with the Different Processing on the Performances of Male Etawa Crossbred Goat}

\author{
Okni Winda Artanti, Muhammad Ridla, Lilis Khotijah \\ Department of Nutrition and Feed Technology Science, Faculty of Animal Science, \\ Bogor Agricultural University \\ Jl. Raya Dramaga, Kampus IPB Dramaga Bogor, West Java, 16680 \\ E-mail: okniwinda@gmail.com
}

\begin{abstract}
The objective of this experiment was to evaluate the effect of fresh, dried or silage cassava leaf to the performances of male Etawa Crossbreed (EC) goats. Fourteen male EC goats (grouping based on body weight with a weight range K1: 19-20 kg; K2:20-21 kg; K3:21-22 kg; K4: $22 \mathrm{~kg}$ ) were allocated in housed individually throughout 90-day trial duration (14 days for animal's adaptation to the experimental diets and 7 days of faeces collection). Experimental design was randomized complete block design consisted of 3 treatments and 4 replications: concentrate + fresh cassava leaf (TO); concentrate + dried cassava leaf (T1); and concentrate + silage cassava leaf (T2). Concentrat was given at level of 50\% (3\% BW) and forage was given ad libitum respectively for each treatments. Variables observed were feed intake, digestibility, body weight gain, and feed efficiency. Data were analyzed using analysis of variance (ANOVA), if there were significant effect of treatments were continued using Duncan multiple range test. The results of this experiment showed that the processing of cassava leaf increased on dry matter intake, crude protein, total digestible nutrient (TDN), digestibility, body weight gain, and feed efficiency. The conclusions were processing of cassava leaves improved the consumption and digestibility of male EC goats and the treatment of cassava leaf silage had the best feed efficiency.
\end{abstract}

Keywords: Cassava Leaf, Performance, Digestibility, Male Etawa Crossbreed Goat.

\section{PENDAHULUAN}

Penduduk Desa Harapan Rejo, Kecamatan Seputih Agung, Kabupaten Lampung Tengah sebagian besar merupakan petani singkong dan peternak kambing yang berbasis peternakan rakyat. Pemberian pakan pada ternak kambing di Desa Harapan Rejo berupa daun ubi kayu yang pada musim panen ketersediaannya sangat melimpah, tetapi memiliki sifat yang mudah busuk apabila hanya ditumpuk dalam keadaan segar. Ketersediaan daun ubi kayu yang cukup melimpah mendorong perlunya dilakukan pengolahan guna memperpanjang masa simpan serta mempertahankan kualitas nutriennya.

Pengolahan pakan dapat dilakukan dengan cara pengeringan atau biofermentasi (ensilase). Metode pengeringan sangat bergantung pada cuaca. Kelemahan pada pengeringan daun ubi kayu, daun akan menjadi remah dan mudah hancur sehingga akan banyak biomasa daun yang hilang terutama pada saat penjemuran, pengangkutan, dan penyimpanan (Marhaeniyanto, 2007). Pembuatan ensilase dapat dilakukan setiap saat tanpa dipengaruhi oleh musim, sehingga ensilase merupakan alternatif metode pengawetan daun ubi kayu.

Pemanfaatan kelimpahan produksi biomasa pada musim hujan secara maksimal perlu dilakukan walaupun daun ubi kayu mampu berproduksi dengan baik pada musim kemarau. Pembuatan ensilase daun ubi kayu sebagai upaya meningkatkan cadangan pakan berkualitas dengan harga kompetitif dan tersedia sepanjang waktu, selain itu daun ubi kayu juga mengandung senyawa asam sianida $(\mathrm{HCN})$ yang terdapat dalam getah, yang bila diberikan dalam keadaan segar dapat mengakibatkan keracunan pada ternak dan dapat menyebabkan kematian (Soto-Blanco dan Gorniak, 2010).

Faktor pembatas penggunaan daun ubi kayu sebagai pakan utama ternak adalah adanya 
kandungan $\mathrm{HCN}$ yang berasal dari senyawa sianogen glukosida. Kadar glukosida sianogenik pada daun berkisar 200-1300 ppm HCN per kg berat segar (Siritunga et al., 2003). Yuningsih (2007) melaporkan bahwa ketika senyawa sianogen glukosida masuk ke dalam usus dan terhidrolisis dengan cepat, maka ion $\mathrm{CN}^{-}$akan dilepaskan, kemudian masuk ke dalam peredaran darah dan menghambat pernafasan sel dengan mengubah pembentukan $\mathrm{Hb}\left(\mathrm{Fe}^{2+}\right)$ menjadi Met $\mathrm{Hb}\left(\mathrm{Fe}^{3+}\right)$ dalam darah. Akibatnya darah tidak mampu membawa oksigen, sehingga jaringan kekurangan oksigen (hypoxia) yang ditandai dengan perubahan warna darah yaitu dari warna merah menjadi warna merah terang. Apabila kandungan Met $\mathrm{Hb}$ dalam darah mencapai 8090\% maka dapat menyebabkan kematian pada ternak.

Puspitaning (2015) melaporkan bahwa penggunaan silase daun ubi kayu dapat menggantikan konsentrat dengan taraf yang sama yaitu $20 \%$ pada ransum domba. Silase juga dapat menurunkan kadar HCN yang tinggi pada daun ubi kayu. Sudarman et al. (2016) melaporkan bahwa konsentrasi HCN daun ubi kayu sebanyak $333,01 \mathrm{mg} / \mathrm{kg}$ turun menjadi $71,04 \mathrm{mg} / \mathrm{kg}$ setelah diterapkan teknologi silase, oleh karena itu pembuatan biofermentasi (ensilase) daun ubi kayu merupakan salah satu metode penanggulangannya.

\section{MATERI DAN METODE}

\section{Materi}

Penelitian ini dilaksanakan pada Juli sampai dengan Oktober 2018. Pengolahan pakan dan pemeliharaan dilaksanakan di peternakan rakyat Desa Harapan Rejo, Kecamatan Seputih Agung, Kabupaten Lampung Tengah, Provinsi Lampung. Analisis proksimat dilaksanakan di Pusat Penelitian Sumberdaya Hayati dan Bioteknologi, Lembaga Penelitian dan Pemberdayaan Masyarakat, Institut Pertanian Bogor. Analisis asam sianida dilakukan di Balai Besar Industri Agro, Bogor.

Tabel 1. Komposisi bahan pakan dan kandungan nutrien konsentrat

\begin{tabular}{lc}
\hline Bahan pakan & Proporsi (\%) \\
\hline Komposisi bahan pakan & 28 \\
Bungkil sawit & 54 \\
Onggok & 17,5 \\
Dedak & 0,5 \\
Premix & 100 \\
Total & \\
\hline Kandungan nutrien konsentrat (\% BK) & 100 \\
Bahan Kering & 11,09 \\
Protein Kasar & 17,84 \\
Serat Kasar & 16,42 \\
Lemak Kasar & 4,57 \\
Abu & 50,09 \\
BETN & 67,38 \\
TDN & 29 \\
\hline
\end{tabular}

Keterangan: Hasil analisis proksimat. Premix yang digunakan tersusun dari calcium 50\%, phospor 25\%, manganese $0,35 \%$, iodium $0,20 \%$, kalium $0,10 \%$, cupprum $0,15 \%$, sodium $15 \%$, iron $0,80 \%$. magnesium 0,15\%, dan zincum 0.20\% . BETN = Bahan Ekstrak Tanpa Nitrogen, dan TDN = Total Digestible Nutrient. TDN dihitung berdasarkan Kearl (1982).

Peralatan yang digunakan antara lain peralatan kandang (12 unit kandang kambing individu, tempat pakan, tempat minum, timbangan, dan silo dengan kapasitas 200 liter) serta peralatan uji laboratorium (satu set peralatan analisis proksimat). Bahan yang digunakan antara lain pakan konsentrat (bungkil sawit, onggok, dan dedak) dan hijauan, yaitu daun ubi kayu (segar, kering, dan silase) dengan pemberian ad libitum.. Ternak yang digunakan adalah 12 ekor kambing PE jantan dengan pengelompokkan berdasarkan bobot badan K1: 19-20 kg; K2: 20-21 kg; K3: 21 $22 \mathrm{~kg}$; dan K4: $22 \mathrm{~kg}$. Komposisi bahan pakan dan kandungan nutrien konsentrat disajikan pada Tabel 1.

\section{Metode}

Rancangan yang digunakan Rancangan Acak Kelompok (RAK) terdiri atas 3 perlakuan dan 4 ulangan. Data yang diperoleh dianalisis menggunakan sidik ragam (ANOVA). Apabila perlakuan menunjukkan pengaruh yang nyata, 
maka dilakukan uji jarak berganda Duncan (Steel dan Torrie, 1995). Analisis data dilakukan menggunakan software statistik SPSS versi 16. Perlakuan terdiri dari:

P0 : $50 \%$ konsentrat $(3,5 \%$ bobot awal $)+$ daun ubi kayu segar ad libitum

P1 : $50 \%$ konsentrat (3,5\% bobot awal) + daun ubi kayu kering ad libitum

P2 : 50\% konsentrat $(3,5 \%$ bobot awal $)+$ silase daun ubi kayu ad libitum

\section{Pembuatan daun ubi kayu kering dan silase}

Daun ubi kayu dipanen dari peternakan rakyat di Harapan Rejo. Pemanenan dilakukan pada sore hari pukul 15.00 WIB. Daun ubi kayu dipilih dari campuran daun, tangkai dan batang pucuk, kemudian dipotong-potong dengan ukuran panjang sekitar 3-5 cm.

Pada perlakuan daun ubi kayu kering, setelah pencacahan daun ubi kayu dijemur dibawah sinar matahari selama 2-3 hari dari pukul 08.00-15.00 WIB. Pada perlakuan silase daun ubi kayu, setelah dicacah kemudian dimasukkan ke dalam silo dan dilakukan pemadatan untuk mencapai kondisi anaerob sebelum ditutup rapat dan diinkubasi selama 21 hari. Silase dibuat dengan menggunakan silo kapasitas 200 liter, hal ini bertujuan agar tidak mudah bocor.

\section{Pemeliharaan Kambing}

Kambing jantan sebanyak 12 ekor dilakukan pemeliharaan selama 90 hari. Adaptasi ransum dilakukan selama dua minggu pertama dengan memberikan pakan perlakuan secara bertahap. Konsentrat yang digunakan terdiri atas bungkil sawit, onggok, dedak, dan premix. Pemberian konsentrat sebanyak 50\% dari total kebutuhan dan daun ubi kayu perlakuan (segar, kering, dan silase) diberikan secara ad libitum. Pembatasan pemberian konsentrat bertujuan agar performa ternak dapat dipengaruhi oleh konsumsi daun ubi kayu. Pemberian air minum secara $a d$ libitum dan sisa pakan ditimbang setiap pagi hari. Koleksi feses dilakukan pada akhir pemeliharaan selama tujuh hari. Pengukuran pertambahan bobot badan harian $(\mathrm{PBBH})$ dilakukan dengan penimbangan ternak yang dilakukan setiap dua minggu sekali. Konsentrat disusun berdasarkan kebutuhan nutrien menurut NRC (2007) untuk kambing dengan bobot badan 20-30 kg.

Proporsi ransum yaitu 50\% konsentrat dari $3.5 \%$ bahan kering berdasarkan bobot badan awal yang bertujuan untuk memenuhi kebutuhan hidup pokok kambing. Konsentrat diberikan di pagi hari pukul 07.00 WIB, setelah konsentrat habis dikonsumsi daun ubi kayu (segar, kering, dan silase) diberikan secara ad libitum. Daun ubi kayu diberikan sebanyak tiga kali yaitu pada pukul 10.00 WIB, 13.00 WIB, dan 16.00 WIB. Ransum yang disusun berdasarkan bahan pakan yang biasa digunakan oleh peternak di Desa Harapan Rejo Kecamatan Seputih Agung. Air minum diberikan secara ad libitum. Sisa pakan ditimbang setiap pagi hari.

\section{Peubah yang diamati}

Peubah yang diamati meliputi konsumsi nutrien yang terdiri dari bahan kering, protein kasar, kecernaan bahan kering, kecernaan bahan organik, total digestible nutrient, pertambahan bobot badan harian ternak, dan efisiensi penggunaan pakan.

\section{HASIL DAN PEMBAHASAN}

\section{Kandungan sianida daun ubi kayu}

Kandungan nutrien dan $\mathrm{HCN}$ daun ubi kayu perlakuan disajikan pada Tabel 2. Hasil analisis menunjukkan bahwa kadar HCN setelah dilakukan pengolahan baik melalui silase maupun dengan penjemuran mengalami penurunan. Penurunan kandungan sianida setelah dilakukan penjemuran selama 2-3 hari yaitu sebesar $85,58 \%$.

Hal tersebut disebabkan oleh salah satu sifat sianida yaitu dapat menguap. Novita (2015) melakukan penjemuran daun ubi kayu dengan waktu yang lebih cepat yaitu selama 6 jam mampu menurunkan HCN sebanyak $13,10 \%$. Penelitian Padmaja (1995) juga menunjukkan bahwa pengeringan di bawah sinar matahari lebih baik jika dibandingkan pengeringan menggunakan oven. Hal tesebut disebabkan oleh adanya kontak berkepanjangan antara linamarase dan glukosida di bawah sinar matahari. Senyawa glukosida sianogenik dengan adanya enzim linamarase ( $\beta$ glukosidase) akan terhidrolisa menjadi acetocyanohidrin dan glukosa, selanjutnya acetocyanohidrin akan terurai menjadi hidrogen sianida (HCN) dan aceton pada pH di atas 5 (Haque, 2004) dan menguap di bawah sinar matahari sehingga menurunkan kadar sianida pada daun ubi kayu.

Kandungan sianida pada daun ubi kayu juga dapat diturunkan melalui teknologi silase dikarenakan silase memiliki kandungan bakteri asam laktat. Hasil penelitian Achi dan Akomas (2006) menunjukkan bahwa bakteri asam laktat berperan dalam proses penurunan sianida karena adanya aktivitas enzim $\beta$-glukosidase yang dihasilkan oleh bakteri asam laktat terutama $L$. mesenteroides. Bakteri L. mesenteroides dapat mendegradasi sianida lebih baik dibandingkan bakteri asam laktat lain, karena mempunyai 
aktivitas $\beta$-glukosidase yang tinggi (Kobawila et al. 2005). Berdasarkan Tabel 2, kandungan sianida pada daun ubi kayu turun menjadi 73 $\mathrm{mg} / \mathrm{kg}$ setelah diterapkan teknologi silase. Angka tersebut masih tergolong aman untuk dikonsumsi oleh ternak. Menurut Tewe (2001), konsumsi HCN tidak bermasalah bagi ternak sampai batas $100 \mathrm{mg} / \mathrm{kg}$ berat segar.

Tinggi rendahnya penurunan kandungan sianida sangat terkait dengan kandungan karbohidrat mudah larut dari suatu bahan, semakin banyak karbohidrat mudah larut maka semakin banyak bakteri memanfaatkan nutrien tersebut sehingga jumlah dan jenis bakteri yang dihasilkan juga relatif banyak. Pada penelitian ini pembuatan silase tidak menggunakan aditif, sehingga substrat yang digunakan untuk memproduksi bakteri asam laktat (BAL) hanya berasal dari Water Soluble Carbohydrate (WSC) daun ubi kayu. Downing et al. (2008) menyatakan bahwa hijauan yang baik untuk dijadikan silase harus mempunyai substrat mudah terfermentasi dalam bentuk WSC yang cukup.

Menurut Jones et al. (2004) apabila kandungan WSC pada bahan rendah, maka fermentasi tidak berjalan sempurna karena produksi asam laktat akan berhenti. Syahniar (2018) melaporkan bahwa proporsi asam laktat pada silase daun ubi kayu setelah dilakukan penyimpanan selama empat minggu baik dengan ataupun tanpa penggunaan aditif menunjukkan rataan proporsi asam laktat mencapai sekitar $73.5 \%$ (37 g/kg BK), sehingga silase tersebut termasuk ke dalam silase berkualitas baik atau sering disebut well-preserved. Syahniar (2018) menduga bahwa kualitas well-preserved pada silase daun ubi kayu tanpa penambahan aditif disebabkan karena daun ubi kayu mempunyai karakteristik yang berbeda dengan kebanyakan silase hijauan lain yang berprotein tinggi. Hal tersebut kemungkinan disebabkan oleh pengaruh tingginya anti nutrisi yang terdapat di dalam daun ubi kayu yaitu asam sianida (HCN).

\section{Konsumsi nutrien ransum}

Banyaknya jumlah pakan yang dikonsumsi oleh ternak merupakan salah satu faktor penting yang secara langsung mempengaruhi produktivitas ternak seperti pertambahan bobot badan. Hasil penelitian menunjukkan bahwa pengeringan daun ubi kayu sangat nyata $(\mathrm{P}<0,01)$ meningkatkan konsumsi bahan kering (BK) (Tabel 3). Rataan konsumsi BK pada perlakuan P1 yaitu sebesar 916 g/ekor/hari atau setara dengan $4,4 \%$ dari bobot badan.

Tabel 2. Kandungan nutrien dan asam sianida (HCN) daun ubi kayu perlakuan

\begin{tabular}{lrrr}
\hline \multicolumn{1}{c}{ Analisis Kimia } & \multicolumn{3}{c}{ Daun Ubi Kayu } \\
\cline { 2 - 4 } & Segar & Kering & Silase \\
\hline Bahan Kering (\%) & 21,60 & 93,00 & 27,00 \\
Protein Kasar (\% BK) & 23,07 & 23,56 & 24,67 \\
Serat Kasar (\% BK) & 20,76 & 19,99 & 20,66 \\
Lemak Kasar (\% BK) & 7,50 & 7,06 & 6,30 \\
Abu (\% BK) & 8,10 & 5,74 & 9,50 \\
Bahan Ekstrak Tanpa Nitrogen (\% BK) & 47,97 & 51,21 & 46,39 \\
Total Digestible Nutrient (\%) & 71,87 & 71,34 & 71,52 \\
Kandungan HCN (mg/kg) & 215 & 31 & 73 \\
Penurunan HCN (\%) & - & 85,58 & 66,04 \\
\hline Keterangan: Hasil anas
\end{tabular}

Keterangan: Hasil analisis proksimat dan asam sianida. TDN dihitung berdasarkan Hartadi (1980).

Tabel 3. Konsumsi dan kecernaan nutrien ransum

\begin{tabular}{lrrr}
\hline \multirow{2}{*}{ Peubah } & \multicolumn{3}{c}{ Perlakuan } \\
\cline { 2 - 4 } & \multicolumn{1}{c}{ P0 } & \multicolumn{1}{c}{ P1 } & \multicolumn{1}{c}{ P2 } \\
\hline Konsumsi bahan kering (g/ekor/hari) & $602,85 \pm 79,08^{\mathrm{b}}$ & $916,32 \pm 34,19^{\mathrm{a}}$ & $686,80 \pm 24,34^{\mathrm{b}}$ \\
Konsumsi protein kasar (g/ekor/hari) & $98,41 \pm 3,12^{\mathrm{b}}$ & $136,32 \pm 5,09^{\mathrm{a}}$ & $103,78 \pm 4,15^{\mathrm{b}}$ \\
Kecernaan bahan kering (\%) & $67,17 \pm 3,40^{\mathrm{b}}$ & $75,76 \pm 2,00^{\mathrm{a}}$ & $76,31 \pm 1,46^{\mathrm{a}}$ \\
Kecernaan bahan organik (\%) & $66,15 \pm 3,50^{\mathrm{b}}$ & $75,17 \pm 2,05^{\mathrm{a}}$ & $75,00 \pm 1,53^{\mathrm{a}}$ \\
TDN (\%) & $70,36 \pm 3,80^{\mathrm{b}}$ & $77,00 \pm 1,94^{\mathrm{a}}$ & $76,35 \pm 1,40^{\mathrm{a}}$ \\
\hline
\end{tabular}

Keterangan: $\mathrm{P} 0=50 \%$ konsentrat (3,5\% bobot awal) + daun ubi kayu segar ad libitum; $\mathrm{P} 1=50 \%$ konsentrat (3,5\% bobot awal) + daun ubi kayu kering ad libitum; $\mathrm{P} 2=50 \%$ konsentrat $(3,5 \%$ bobot awal $)$ + daun ubi kayu silase ad libitum. Huruf yang berbeda pada baris yang sama menunjukkan perbedaan yang nyata $(\mathrm{P}<0,05)$. 
Jumlah konsumsi pada daun ubi kayu kering di atas kebutuhan ternak berdasarkan NRC (2007) yang merekomendasikan bahwa untuk memenuhi kebutuhan hidup pokok kambing membutuhkan bahan kering yaitu sebesar 3,26\% dari bobot badan. Sementara pada daun ubi kayu segar (P0) dan silase (P2) konsumsi relatif lebih rendah dari rekomendasi NRC. Hal ini mengindikasikan bahwa kadar $\mathrm{HCN}$ yang terkandung di dalam daun ubi kayu tersebut menjadi faktor pembatas konsumsi bahan kering pada kambing perlakuan, sehingga daun ubi kayu yang mengandung $\mathrm{HCN}$ tinggi tingkat palatabilitasnya akan lebih rendah.

Perlakuan daun ubi kayu segar (P0) tidak menunjukkan pengaruh negatif yang timbul pada ternak. Hal ini disebabkan oleh kambing sudah terbiasa mengonsumsi daun ubi kayu sebagai hijauan sehingga mikroba rumen dapat menghasilkan enzim yang membantu proses pendegradasi sianida. Hal tersebut diperkuat oleh laporan Abrar (2001) yang telah menemukan bakteri dengan karakteristik mirip dengan Megaspaera elsdenii pada cairan rumen domba yang terbiasa mengonsumsi daun ubi kayu.

Megaspaera elsdenii memiliki
kemampuan mendegradasi HCN sehingga tidak menimbulkan dampak negatif dari ternak tersebut. Ternak yang terbiasa dengan ransum berkadar serat kasar tinggi maka mikroba yang dominan adalah mikroba pencerna serat, begitu pula dengan ternak yang terbiasa mengonsumsi hijauan dengan kandungan sianida maka mikroba yang dominan adalah mikroba pendegradasi sianida. Mathius et al. (1998) melaporkan bahwa domba yang diberi pakan berupa daun ubi kayu manis secara tunggal (tanpa campuran bahan pakan lain) tidak menimbulkan efek kelainan klinis. Hal tersebut dikarenakan komposisi dan populasi mikroba yang hidup dalam rumen ditentukan oleh jenis pakan yang dikonsumsi oleh ternak tersebut dan interaksi antar mikroba rumen (Preston and Leng, 1987).

Perbedaan konsumsi bahan kering yang signifikan juga mempengaruhi konsumsi protein kasar (PK). Konsumsi protein kasar harian kambing pada penelitian ini sudah memenuhi kebutuhan protein kambing jantan fase produksi sesuai dengan rekomendasi dari NRC (2007) yang menyatakan bahwa kebutuhan protein kasar pada kambing fase produksi yaitu 80-110 g/ekor/hari. Hal tersebut mengindikasikan bahwa pemberian daun ubi kayu sebagai pakan sudah mencukupi kebutuhan protein kasar pada kambing PE.

\section{Kecernaan Nutrien Ransum}

Nilai kecernaan bahan kering pada penelitian ini berkisar antara 67,17-76,31\% dan bahan organik berkisar antara 66,15-75,17\% . Hasil analisis statistik menunjukkan bahwa pengolahan daun ubi kayu sangat nyata $(\mathrm{P}<0,01)$ meningkatkan kecernaan bahan kering dan nyata $(\mathrm{P}<0,05)$ meningkatkan kecernaan bahan organik (Tabel 4). NRC (2007) melaporkan bahwa standar kecernaan bahan kering pada ternak ruminansia yaitu sebesar 50-75\%. Hal ini menunjukkan bahwa kecernaan pada perlakuan masih dalam batas normal. Hasil kecernaan bahan kering pada penelitian ini juga sejalan dengan Noveanto (2013) yang melaporkan bahwa rataan kecernaan bahan kering pada domba yang diberi pakan silase daun ubi kayu sebesar 69,57$79,15 \%$. Nilai kecernaan bahan organik pada penelitian ini sejalan dengan kecernaan bahan organik penelitian Riswan (2017) yang berkisar antara 72,00-75,68\%.

Kandungan energi pakan ternak ruminansia ditentukan berdasarkan kandungan TDN (Total Digestible Nutrien), semakin tinggi nilai TDN pakan maka semakin baik kualitas pakan yang dikonsumsi karena banyak zat-zat makanan yang dapat diserap oleh tubuh dan tidak diekskresikan melalui feses. Hasil analisis ragam menunjukkan bahwa pengolahan daun ubi kayu nyata $(\mathrm{P}<0,05)$ meningkatkan nilai TDN. Rataan nilai TDN pada penelitian ini lebih tinggi bila dibandingkan dengan penelitian Riswan (2017), pemberian bakteri pendegradasi $\mathrm{HCN}$ dan suplementasi sulfur pada ransum domba mengandung tepung daun ubi kayu pahit menghasilkan TDN sebesar 67,31-70,75\% . Berdasarkan NRC (2007) bahwa kebutuhan energi dalam bentuk TDN untuk kambing fase penggemukan adalah sebesar $44 \%$. Tingginya nilai TDN menunjukkan banyaknya zat makanan yang dapat dimanfaatkan oleh ternak untuk memenuhi kebutuhan hidup pokok dan produksi. Kekurangan energi akan menghambat pertambahan bobot badan ternak serta terhambatnya fungsi produksi. Ternak memanfaatkan energi untuk pertumbuhan dan produksi setelah kebutuhan hidup pokoknya terpenuhi. Kebutuhan energi akan meningkat seiring dengan bertambahanya bobot badan ternak, namun apabila kelebihan energi akan disimpan dalam bentuk lemak tubuh dan sebaliknya apabila ternak kekurangan energi maka akan merombak lemak tubuh untuk mencukupi kebutuhan energi untuk hidup pokok ternak. 


\section{Pertambahan Bobot Badan Harian dan Efisiensi Pakan}

Pertambahan bobot badan harian ternak (PBBH) dapat digunakan sebagai salah satu indikasi untuk mengevaluasi kualitas bahan pakan ternak. Bahan pakan yang berkualitas baik akan menghasilkan kambing dengan PBBH yang tinggi, semakin tinggi pertambahan bobot badan kambing maka akan menghasilkan keuntungan yang besar bagi para peternak. PBBH digunakan untuk mengetahui performa produksi ternak. PBBH penelitian ini berkisar antara 52,77-83,33 g/ekor/hari (Tabel 4).

Perlakuan tidak berpengaruh nyata terhadap pertambahan bobot badan harian ternak, tetapi apabila dilihat dari nilainya maka $\mathrm{PPBH}$ perlakuan daun ubi kayu segar (P0) yang dihasilkan lebih kecil dibandingkan dengan kedua perlakuan. Hal ini menunjukkan bahwa pemberian daun ubi kayu segar secara ad libitum mampu menghambat penggunaan nutrien dalam tubuh ternak. Ternak yang diberikan perlakuan berupa daun ubi kayu kering (P1) memiliki pertambahan bobot badan harian yang lebih dibandingkan dengan perlakuan lain yaitu P0 dan P1. Hal ini disebabkan oleh ternak dengan pemberian daun ubi kayu kering (P1) memiliki konsumsi pakan yang lebih tinggi bila dibandingkan dengan perlakuan lain sehingga pertambahan bobot badan yang dihasilkan juga lebih tinggi.

Rataan pertambahan bobot badan harian (PBBH) kambing dengan perlakuan silase daun ubi kayu pada penelitian ini lebih tinggi dibandingkan dengan penelitian lainnya, yaitu 48,57 g/ekor/hari ketika diberikan silase daun ubi kayu pahit pada taraf pemberian $40 \%$ (Noveanto, 2013) dan 30,18-31,90 g/ekor/hari dengan menggunakan silase daun ubi kayu pada taraf 20\% (Puspitaning, 2015).

Efisiensi pakan dihitung berdasarkan perbandingan antara pertambahan bobot badan harian ternak dengan konsumsi bahan kering harian. Pemberian silase daun ubi kayu (P2) memiliki nilai efisiensi pakan yang cenderung lebih tinggi dibandingkan dengan daun ubi kayu kering (P1) dan segar (P0). Pada perlakuan daun ubi kayu kering (P1) walaupun pertambahan bobot badan harian $(\mathrm{PBBH})$ yang dihasilkan lebih tinggi, akan tetapi konsumsi ransum sangat signifikan juga lebih tinggi dibandingkan dengan daun ubi kayu segar dan silase. Sehingga efisiensi penggunaan pakan menjadi lebih rendah dibandingkan dengan pemberian silase (P2).

Tabel 4. Pertambahan bobot badan harian dan efisiensi penggunaan pakan

\begin{tabular}{ccccc}
\hline \multirow{2}{*}{ Perlakuan } & \multicolumn{4}{c}{ Peubah } \\
\cline { 2 - 5 } & $\begin{array}{c}\text { BB awal } \\
(\mathbf{k g})\end{array}$ & $\begin{array}{c}\text { BB akhir } \\
(\mathbf{k g})\end{array}$ & $\begin{array}{c}\text { PBBH } \\
(\mathbf{g})\end{array}$ & $\begin{array}{c}\text { Efisiensi pakan } \\
(\boldsymbol{\%})\end{array}$ \\
\hline \hline P0 & $20,50 \pm 1,29$ & $25,25 \pm 3,94$ & $52,77 \pm 30,59$ & $8,92 \pm 5,07$ \\
P1 & $20,75 \pm 1,25$ & $28,25 \pm 2,50$ & $83,33 \pm 21,27$ & $9,25 \pm 2,32$ \\
P2 & $21,75 \pm 1,10$ & $27,50 \pm 1,73$ & $69,44 \pm 26,25$ & $11,63 \pm 4,15$ \\
\hline
\end{tabular}

Keterangan: $\mathrm{P} 0=50 \%$ konsentrat (3,5\% bobot awal) + daun ubi kayu segar ad libitum; $\mathrm{P} 1=50 \%$ konsentrat $(3,5 \%$ bobot awal $)+$ daun ubi kayu kering ad libitum; $\mathrm{P} 2=50 \%$ konsentrat $(3,5 \%$ bobot awal $)$ + daun ubi kayu silase ad libitum.

\section{SIMPULAN}

Berdasarkan hasil penelitian yang telah dilakukan dapat disimpulkan bahwa:
1. Pengolahan daun ubi kayu dapat meningkatkan konsumsi bahan kering dan protein kasar, kecernaan bahan kering dan bahan organik, dan nilai TDN ternak.
2. Nilai efisiensi pakan silase daun ubi kayu cenderung lebih baik jika dibandingkan dengan jenis pakan lainnya

\section{DAFTAR PUSTAKA}

Abrar, A. 2001. Eksplorasi Mikroba Rumen Pendegradasi Sianida. Tesis. Institut Pertanian Bogor. Bogor.
Achi, O., S. Akomas 2006. Comporative assessment of fermentation techniques in the processing of fufu, a tradisional fermented cassava product. Pak. J. Nutr. 5: 224-229.

Downing, T.W., A. Buysereie, Gamroth, P. French 2008. Effect of water soluble carbohydrates on fermentation characteristics of ensilade perenial ryegrass. Prof. Anim. Scienctist. 24: 3539.

Haque, 2004. Preparation of Linamarin From Cassava Leaves for Use in Cassava Cyanide Kit. Food Chemistry 85: 27-29.

Jones, C. M, A. J. Heinrichs, G. W. Roth, V. A Issler. 2004. From Harvest to Feed : Understanding Silage Management. 
Pensylvania State University. Pensylvania.

Kearl, L.C. 1982. Nutrient Requirements of Ruminants in Developing Countries. In: International Feedstuffs Utah Agriculture Experiment Station (1st ed). Utah State University, Logan.

Marhaeniyanto, E. 2007. Pemanfaatan daun ubi kayu untuk pakan ternak kambing. Buana. 7(1): 71-82.

Mathius, I. W, B. Haryanto, dan I. W. R. Susana. 1998. Pengaruh pemberian protein dan energi terlindungi terhadap konsumsi dan kecernaan oleh mikroba muda. Jurnal Ilmu Ternak dan Veteriner. 3(2): 94-100.

Novita, M. 2015. Isolasi, Identifikasi, dan Karakterisasi serta Inokulasi Bakteri Pendegredasi Sianida dari Cairan Rumen Kambing Peranakan Etawa secara In Vitro. Tesis. Institut Pertanian Bogor. Bogor.

National Research Council. 2007. Nutrient Requirement of Small Ruminants. National Academies Press, Washington, DC.

Noveanto, I. 2013. Kecernaan Nutrien, Retensi Nitrogen, dan Sintesis Protein Mikroba pada Domba yang Mendapat Substitusi Konsentrat dengan Silase Daun Singkong (Manihot Esculenta Sp.): Penelitian Lapang. Skripsi. Institut Pertanian Bogor. Bogor.

Padmaja, G. 1995. Cyanide Detoxification in Cassava For Food and Feed Uses. Crit. Rev. Food Sci Nutr. 35(4): 299-339.

Preston, T. R. and R. A Leng. 1987. Matching Ruminant Production System with Avaible Resources in the Tropics and SubTropics. Penambul Book. Armidale, Australia. Pp. 245.

Puspitaning, I. 2015. Performa, Status Nutrisi dan Karakteristik Fermentasi Rumen pada Domba yang Dipelihara Peternak Desa Petir Kecamatan Dramaga Kabupaten
Bogor: Penelitian Lapang. Tesis. Institut Pertanian Bogor. Bogor.

Riswan, M. 2017. Performa dan Kecernaan Domba yang Diberi Bakteri Pendegradasi HCN dan Suplementasi Sulfur pada Pakan Mengandung Daun Singkong Pahit (Manihot glaziovii). Skripsi. Institut Pertanian Bogor. Bogor.

Siritunga, D, T. Richard, dan Sayre. 2003. Generation of Cyanogenics - Free Transgenic Cassava. Planta. 217: 367373.

Soto-Blanco B, S.L. Gorniak. 2010. Toxic effects of prolongedadministration of leaves of cassava (Manihot esculenta Crantz) to goats. Experimental and Toxicology Pathology. 62: 361-366.

Steel, R. G. D. and J. H. Torrie. 1995. Prinsip dan Prosedur Statistik Suatu Pendekatan Biometrik. Gramedia Pustaka Utama. Jakarta.

Sudarman, A., M. Hayashida, , I.R. Puspitaning, A. Jayanegara dan H. Shiwachi. 2016. The Use of Cassava Leaf Silage as a Substitute for Concentrate Feed in Sheep. Trop Anim Health Prod. 48(7): 09-12.

Syahniar M.T., M. Ridla, A. Jayanegara, A. Samsudin. 2018. Effects of glycerol and chestnut tannin addition in cassava leaves (Manihot esculenta Crantz) on silage quality and in vitro rumen fermentation profiles. App. Anim. Res. 46 (1): 1207-1213.

Tewe, O.O. 1991. Detoxxification of Cassava Products and Effects of Residue Toxins on Consuming Animals. In; Ropts, tubers, plantains and bananas in animal feeding (Editors: Machin D, Solveig N). FAO Animal Production and Health paper 95: 81-95.

Yuningsih, 2007. Kasus Keracunan pada Hewan di Indonesia. Jurnal Litbang Pertanian 26(4): 153-159. 